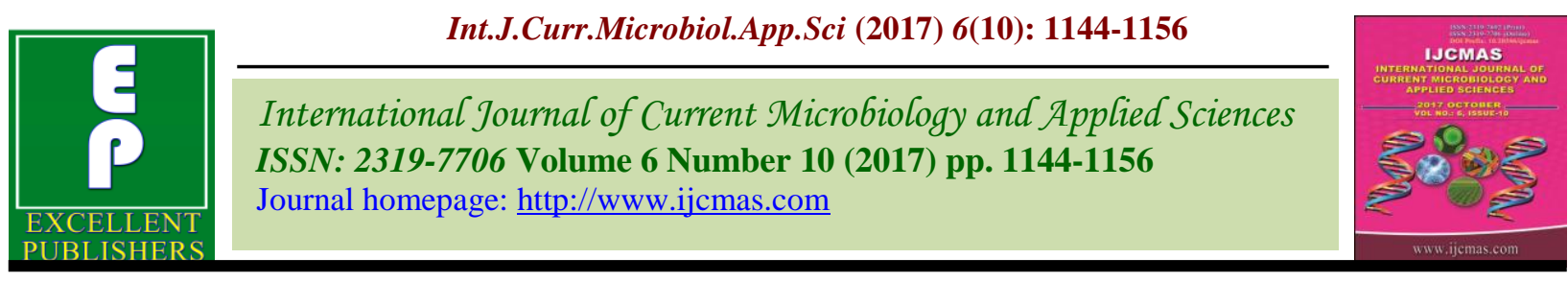

Review Article

https://doi.org/10.20546/ijcmas.2017.610.138

\title{
Rice Husk and Its Applications: Review
}

\author{
Patil Nita Babaso* and H. Sharanagouda \\ Department of Processing and Food Engineering, University of Agricultural Sciences, \\ Raichur- 584104, Karnataka, India \\ *Corresponding author
}

\begin{tabular}{|c|c|}
\hline & A B S T R A C T \\
\hline & Rice is staple food of more than half world. Therefore, rice processing and \\
\hline & associated business are growing vigorously. Rice husk obtain from rice milling \\
\hline $\begin{array}{l}\text { Rice husk, Rice husk } \\
\text { ash, Silica, Refractory } \\
\text { industry, Sorbent. }\end{array}$ & $\begin{array}{l}\text { process as by product. It is attracting as value added material for domestic and } \\
\text { industrial processing such as preparing valuable silicon based materials, cement, } \\
\text { as source of pet food fibre and as source of dietary fibre, preparation of activated }\end{array}$ \\
\hline Article Info & carbon, refractory industry, polymer, rubber, preparing sorbent for waste water \\
\hline $\begin{array}{l}\text { Accepted: } \\
\text { 10 September } 2017 \\
\text { Available Online: } \\
10 \text { October } 2017\end{array}$ & $\begin{array}{l}\text { stuffs, ceramic industry and biosynthesis of silica nano-particles. Extensive } \\
\text { research has been done to utilize important properties of rice husk and its ash for } \\
\text { industrial applications. Summarising all these data could be helpful for smooth } \\
\text { future research on rice husk and rice husk ash. }\end{array}$ \\
\hline
\end{tabular}

\section{Introduction}

Rice husks have been attracted as value added material towards waste utilization and cost reduction in domestic and industrial processing. Rice husk $(\mathrm{RH})$ is widely available in rice producing countries like China and India which contributes 33\% and $22 \%$ of global rice production respectively, as by-product of the rice milling. $\mathrm{RH}$ content ranges from 16-25\% of paddy (Della et al., 2002; Giddel et al., 2007; Soltani et al., 2015). Every year approximately 500 million tonne paddy produced by world and 120 million tonnes of paddy produced by India, it gives around 24 million tonnes of $\mathrm{RH}$ per year (Shwetha et al., 2014). Rice husk ash (RHA) is the by-product of $\mathrm{RH}$, when it burnt in ambient atmosphere.
20 million tonnes produced per year by world (Koteswara and Pranav, 2011; Soltani et al., 2015). Due to low density and less commercial interest of $\mathrm{RH}$, handling as well as transportation it is problematic, which creates disposal and serious environmental problems (Pode, 2016).

High-value applications such as the use of RHA in synthesis of silica, activated carbon, silica gels, porous carbon, zeolites, silicon carbide, silicon nitride, manufacturing of silicon chip and light weight construction materials insulations, catalysts, cordierite, ingredients for lithium ion batteries, graphene, energy storage/capacitor, carbon capture. Other applications include in the manufacture 
of soluble silicate, silicones and its alloy, silicon based chemicals, reinforcing filler in natural and synthetic rubber (Karera, 1986; Patel, 1987; Conradt et al., 1992; Krishnarao and Godkhindi, 1992; Wang et al., 1998; Della et al., 2002; Naskar and Chatterjee, 2004; Sun and Tzong-Horng, 2004; Wu et al., 2004; Mohamed et al., 2015; Pode, 2016). Due to lack of awareness of its properties and applications, rice husks are not being utilized effectively. Therefore, application of RH and RHA in domestic and industrial processing not only useful to increase farm income in directly and indirectly way but also it is the alternative solution to disposal problem of $\mathrm{RH}$. In this review we are discussing about composition and applications of RH and RHA in commercial and industrial sectors.

\section{Composition of rice husk}

RH contents are hemicelluloses $24.3 \%$, cellulose $34.4 \%$, lignin $19.2 \%$, ash $18.85 \%$, and the other trace elements $3.25 \%$. Hemicelluloses used as recourse of activated carbon, xylose and silicon dioxide. $\mathrm{RH}$ contents main elemental components as Carbon $37.05 \%$, Hydrogen $8.80 \%$, Nitrogen $11.06 \%$, Silicon $9.01 \%$ and Oxygen $35.03 \%$ (Joseph et al., 1999; Sarang et al., 2009). Husk contains 17-25\% silica (Patel et al., 1987; Conradt et al., 1992; Real et al., 1996). Rice husks have bulk density of 96-100 $\mathrm{kg} / \mathrm{m}^{3}$, hardness (Mohr's scale) 5-6, ash $22.29 \%$, Oxygen $31-37 \%$, Nitrogen 0.23 $0.32 \%$, Sulphur $0.04-0.08 \%$, Hydrogen $4-5 \%$ (Muthadhi et al., 2007). The composition of RH depends on many factors such as rice variety, type of fertilizer used, soil chemistry, and even the geographic localization of the production (Bining and Jenkins, 1992; Muntohar et al., 2002).

\section{Composition of rice husk ash}

$\mathrm{RH}$ is high in ash content as compared to other biomass fuels ranging $14-25 \%$
(Chandrasekhar et al., 2005; Adam et al., 2006). Silica content in RHA varies from 8398\% (Adam et al., 2006; Rozainee et al., 2008 and Pode, 2016). Presence of high amount of silica makes it a valuable material for use in industrial applications. Chemical composition of RHA determined by X-ray fluorescence (XRF) as $\mathrm{SiO}_{2} 89 \%, \mathrm{Al}_{2} \mathrm{O}_{3}$ $1.20 \%, \mathrm{C} 18.24 \%, \mathrm{CaO} 1 \%, \mathrm{~K}_{2} \mathrm{O} 1.22 \%$, $\mathrm{Fe}_{2} \mathrm{O}_{3}$ 1.28\% (Mohamed et al., 2015). There are various factors which affects the ash properties such as, incinerating conditions (temperature and duration), rate of heating, burning technique (Govindarao, 1980; Mansaray and Ghaly, 1999).

\section{Application of rice husk}

Unique physical and chemical properties of $\mathrm{RH}$, like high ash content, silica content, it can be effectively used in domestic and industrial processing. Many of reports shown that, $\mathrm{RH}$ is used as fuel for different purpose, such as in brick kilns, in furnaces, in parboiling process of rice, the raw material for the production of sodium silicate, as an cleaning or polishing agent in metal and machine industry, briquettes molecular sieve (Singh, 2000; Ugheoke et al., 2006; Shwetha et al., 2014).

\section{As source of fuel}

The calorific value of $\mathrm{RH}$ is $15217.20 \mathrm{KJ} / \mathrm{Kg}$, efficiency of boiler found same as using of coal (68\%) so RH is cheaper fuel than coal (Yadav and Singh, 2011; Velupillai et al., 1997). Heat energy is produced by direct combustion and gasification of $\mathrm{RH}$, it can be used for several processing such as generation of steam in parboiling of rice (Shwetha et al., 2014; Prasara and Grant, 2011; Yadav and Sing, 2011). RH is potentially used for electric generation. 1 tonne of $\mathrm{RH}$ is required for producing $1 \mathrm{MWH}$ electricity. It is also used as alternative fuel for household energy (Rozainee et al., 2008). Reaction involved in 
fuel reactor according to composition of $\mathrm{RH}$ with 1 mole $\mathrm{C}, 0.6402$ moles hydrogen $\left(\mathrm{H}_{2}\right)$, 0.3052 oxygen $\left(\mathrm{O}_{2}\right)$ as follows (Monga et al., 2015).

$\mathrm{C}+0.6402 \mathrm{H}_{2}(\mathrm{~g})+0.3052 \mathrm{O}_{2}(\mathrm{~g})+2.0298 \mathrm{NiO}$

$=\mathrm{CO}_{2}(\mathrm{~g})+0.6402 \mathrm{H}_{2} \mathrm{O}(\mathrm{g})+2.0298 \mathrm{Ni}$

\section{As sourse of silica and silicon based} materials

Due to high silica content of $\mathrm{RH}$ now, it become a source for a number of silicon compounds, silicon nitride, silicon tetrachloride, including silicon carbide, silica, zeolite, and pure silicon. Also for preparing advanced materials like $\mathrm{SiC}$, elemental $\mathrm{Si}$, $\mathrm{Mg}_{2} \mathrm{Si}, \mathrm{Si}_{2} \mathrm{~N}_{2} \mathrm{O}, \mathrm{SiN}$, silanes (Acharya et al., 1980; Karera et al., 1986; Padhi and Patnaik, 1995; Sun and Gong, 2001; Soltani et al., 2014; Patil et al., 2014). The reaction between $\mathrm{SiO}_{2}$ of rice husk ash and $\mathrm{NaOH}$ can be expressed as the following reaction (Della et al., 2002).

$2 \mathrm{xNaOH}+\mathrm{ySiO} \rightarrow \mathrm{xNa}_{2} \mathrm{O} \cdot \mathrm{ySiO}_{2}+\mathrm{xH}_{2} \mathrm{O}$

Neutralization of the obtained sodium silicate $\left(\mathrm{xNa}_{2} \mathrm{O} \cdot \mathrm{ySiO}_{2}\right)$ gives silica gel as follows (Real et al., 1996)

$x \mathrm{Na}_{2} \mathrm{O} \cdot y \mathrm{SiO}_{2}+\mathrm{xH}_{2} \mathrm{SO} 4 \rightarrow \mathrm{ySiO}_{2}+\mathrm{xNa}_{2} \mathrm{SO}_{4}+$ $\mathrm{xH}_{2} \mathrm{O}$

Silicon carbide ( $\mathrm{Si}-\mathrm{SiC}$ ) also was synthesized from a powder mixture of rice husk ash-C$\mathrm{Mg}$. The overall chemical reactions can be expressed as (Niyomwas, 2009).

$2 \mathrm{SiO}_{2}(\mathrm{~s})+\mathrm{C}(\mathrm{s})+4(\mathrm{Mg})=\mathrm{SiC}(\mathrm{s})+\mathrm{Si}(\mathrm{s})+4 \mathrm{MgO}$

Silicon nitrate is produced by the nitridation of rice husk can be represented by the following reactions (Soltani et al., 2015)

$\mathrm{SiO}_{2}(\mathrm{~s})+\mathrm{C}(\mathrm{s})=\mathrm{SiO}(\mathrm{g})+\mathrm{CO}(\mathrm{g})$
$\mathrm{SiO}_{2}(\mathrm{~s})+\mathrm{CO}(\mathrm{g})=\mathrm{SiO}(\mathrm{g})+\mathrm{CO}_{2}(\mathrm{~g})$

$\mathrm{SiO}(\mathrm{g})+2 / 3 \mathrm{~N}_{2}(\mathrm{~g})=1 / 3 \mathrm{Si}_{3} \mathrm{~N}_{4}(\mathrm{~s})+1 / 2 \mathrm{O}_{2}(\mathrm{~g})$

The amorphous $\mathrm{SiO}_{2}$ was thus reduced to form silicon according to the following reaction (Bose et al., 1993)

$\mathrm{SiO}_{2}+2 \mathrm{Mg}=\mathrm{Si}+2 \mathrm{MgO}+\mathrm{SiO}_{2}$ (unreacted)

\section{As organic fertilizer}

Today, organic fertilizer plays important role in agriculture. RH is utilized as an organic fertilizer to improve not only productivity but also water use efficiency in field (Govindarao1980; Ebaid, et al., 2007; Badar and Qureshi, 2014). Many researchers reported, $\mathrm{RH}$ is used to improve of nitrogen and other macro and micro-elements absorption which enhancing the production and translocation of the dry matter content from source to sink (El-Wehishy and ElHafez, 1997; Awad, 2001; Ebaid et al., 2005; El-Refaee et al., 2006; Ebaid, et al., 2007). $\mathrm{RH}$ is bio transformed of into organic fertilizer through vermicomposting (Lim et al., 2012; Shak et al., 2014). Also it can be used as a source of potassium for growth and yield of cowpea (Priyadharshini and Seran, 2010).

\section{As sourse of pet food fibre and as source of dietary fibre}

Traditionally, $\mathrm{RH}$ has been used as ingredient in ruminant and poultry (Shqueir et al., 1989; Aderolu et al., 2004; Aderolu et al., 2007). Rice husk has more than $30 \%$ dietary fibre, it is also an excellent source of protein and mineral, so it could use in food industry especially developing functional foods.

Enzymatic extraction gives more fiber from rice husk than chemical method $(33.97 \%$ vs. $67.53 \%$ ) and the extracted fiber had higher 
water-binding capacity and exhibited high fat binding capacity (Fadaei et al., 2012).

\section{Used for making bricks (as building material)}

More porous and better thermal insulated brick can be made with high percentage of RH. Due to low thermal conductivity of air entrapped in pores, it makes porous fire brick structure suitable for back up insulation (Chesti, 1986; Ugheoke et al., 2006). More adding rice husk less compressive strength and density of specimens, the porosity increases (Mbiminah, 1992; Sutas et al., 2012; Watile, 2015). RH is excellent alternative material to ordinary portland cement for production brick (Chukwudebelu et al., 2015). It is also used for building of roads in environment-friendly way (Lennox and Mackenzie, 2008).

\section{Preparation of activated carbon}

The unique properties such as high surface area, large adsorption capacity and fast adsorption kinetics makes activated carbons as valuable material for different industrial applications. Production of activated carbon from rice husk is achieved through activation with chemical or physical means (Della et al., 2002; Rahman et al., 2005; Tongpoothorn et al., 2011; Van and Thi, 2014; Alvarez et al., 2015; Mehta and Ugwekar; 2015). The Nano porous activated carbon with large specific area of $2523.4 \mathrm{~m}^{2} \mathrm{~g}^{-1}$ was obtained from $\mathrm{RH}$ (Xu et al., 2014).

The effect of alkali carbonate in the activation process can be related to formation of porosity due to $\mathrm{SiO} 2$ interaction with the carbonates, $\mathrm{CO}_{2}$ reacts with the carbon phase with formation of $\mathrm{CO}$, according following reaction (Soltani et al., 2015)

$\mathrm{M}_{2} \mathrm{CO}_{3}+\mathrm{SiO}_{2}=\mathrm{M}_{2} \mathrm{SiO}_{3}+\mathrm{CO}_{2}$
$\mathrm{CO}_{2}+\mathrm{C}=2 \mathrm{CO}$

Used for removal of toxic metals from waste water

The high silica content of $\mathrm{RH}$ it makes it insoluble in water, having good chemical stability, structural strength (Lee et al., 1994). So it plays important role in water purification as well as in waste water treatment. Sorbent made by RH effectively used to removal of the six heavy metals such as $\mathrm{Fe}, \mathrm{Mn}, \mathrm{Zn}, \mathrm{Cu}$, $\mathrm{Cd}$ and $\mathrm{Pb}$ (Munaf, 2010; Daifullah et al., 2003; Yalcin and Sevinc, 2000). RH is also used as adsorbent to remove various pollutants, phenols, dyes, pesticides, inorganic anions, organic compounds and heavy metals (Chauh et al., 2005; Gupata et al., 2006; Lata and Samadder, 2014).

\section{In production of bioethanol}

Bioethanol productions from RH are the key of solution to problems such as environmental, economic, and energy which are facing all across the world. Bioethanol is effectively produced by RH (Saha and Cotta, 2007; Srivastava, 2014). The global potential production of bioethanol in order of 20.9 to 24.3 GL per annum from RH, it has potential to satisfy around one fifth of the global ethanol bio fuel demand for $10 \%$ gasohol fuel blend (Abbas. 2010. Nyachaka et al., 2013).

\section{Other uses}

High surface porous $\mathrm{SiO}_{2} / \mathrm{C}$ composites from RH were fabricated by heating pellets composed of RH powders with different sizes (Warati et al., 2006). It is used as adsorption of direct dyes from aqueous solution (Wahab et al., 2005). Also used for production of xylitol, furfural, ethanol, acetic acid. It is more useful in a cleaning and polishing agent in metal and machine industries (Zurina et al., 2004; Khalf and Ward 2010; Attharangsan et 
al., 2012). RH has best binding ability, which reduces the formation of cracks. So it is used in preparing of biodegradable pottery products (Ammara et al., 2012). Sometime it is used for the pillow stuffing (Kumar et al., 2013). RH has been used as an industrial raw material for different purpose such as making panel board, insulating board material, fillers in plastics, filling material, building materials Farooquea et al., 2009).

\section{Application of rice husk ash}

RHA plays important role in various industrial applications such as processing of refractory industry, ceramic, cement, fillers of rubber and plastic composites, cement, adsorbent and support of heterogeneous catalysts (Sevdalina et al., 2012). Some of other industrial and domestic applications of RHA are discussing here.

\section{Used as silica source}

The presence of silica in $\mathrm{RH}$ has been known since 1938 (Martin, 1938). Due to its high silicon content RHA has become a source for preparation of silica (Della et al., 2002; Singh et al., 2008; Supakorn et al., 2009; Supitcha et al., 2009; Shelke et al., 2010; Patil et al., 2014). Precipitated silica widely used in many of the industries like electronics, ceramic, paint industry, polymer material, tyre industry, cosmetics, reinforcing agent in rubber, thickening agent in paints, thixotropic agents, thermal insulators, composite fillers, in toothpastes as a cleansing agent and anticaking agent in food industry (Rama-Rao et al., 1989; Dongmin et al., 2010).

\section{In Cement and Concrete Industries}

RHA is used to enhance strength of concrete blocks as the filler in concrete blocks (Cisse, and Laquerbe, 2000). Lime pozzolana mixes with RHA could be a suitable partly replacement for portland cement (Mehta, 1977; Zhang et al., 1996; Nicole et al., 2000; Ganesan et al., 2008; Kartini, 2011; Xu et al., 2014). It is possible to increase compressive and flexural strengths (Zhang et al., 1996; Ismaila, 1996), reduced permeability (Zhang et al., 1996; Ganesan et al., 2007), increased resistance to chemical attack durability and workability (Coutinho, 2002) with use of RHA in concrete.

\section{In polymer industries}

RHA have been used as fillers in polyethylene (Cisse and Laquerbe, 2000, Panthapulakkal et al., 2005), polypropylene (Fuad et al., 1995; Premalal et al., 2002; Ismail, 2002), polystyrene (Ismail, 2003). RH and its thermal degraded products are often used as fillers in paper, paint (Chandrasekhar et al., 2003), polymers (Saheb and Jog, 1999; Choi et al., 2006), polymeric composites (Nassar et al., 2007, Premalal et al., 2003).

\section{In vulcanizing rubber}

To improve mechanical properties of natural rubber materials, incorporation of RHA with additives/silane coupling agent in rubber or rubber/plastic composites enhanced the mechanical/physical properties, filler dispersion and crosslink density (Ismail et al., 1997; Siriwandena et al., 2001; Ismail et al., 2001; Arayapranee et al., 2005). It is also used as fillers for epoxidized natural rubber compounds (Mehta et al., 1995; Ismail et al., 1997).

\section{Manufacturing refractory bricks}

In the manufacturing of refractory brick, RHA can be used profitably (Sutas et al., 2012). The compressive strength of the bricks increased with rice husk ash contents but weight is decreases (Rahman 1988; Amin et al., 2013). As compare to conventional clay 
bricks, rice husk ash admixture bricks, showed lower compressive strength and higher percentage of water absorption (More et al., 2015; Malik and Arora, 2015).

\section{Control of insect pests in stored food stuffs}

RHA is effectively used to control of insects and pests in stored food stuffs. It is used against Callosobruchus maculatus (F) and Sitophilus zeamais (Mots) (Paneru and Shivakoti, 2000/2001; Adebayo and Ibikunle, 2014; Shazia et al., 2006).

Effective as an oil spill absorbent made with RHA used in waterproofing chemicals, flame retardants, and as a carrier for pesticides and insecticides (Kumar et al., 2012). It has shown that to keep stored potatoes free of the potato tuber moth (Phthorimaea operculelle) for up to 5 months of storage, RHA is effectively used (Das and Rahman, 1997).

\section{In the water purification}

Arsenic content in drinking water becoming a main problem in these days. 100 million people across the India are suffering such type of health effect. Its removal with the use of RHA has been investigated (Saha et al., 2002; Malhotra et al., 2013; Adams Bhagavanulu, 2015). RHA acts as adsorbent for the adsorption of lead and mercury from aqueous water (Feng et al., 2004). Methylene blue, humic acid, are removed by RHA from wastewater (Imyim et al., 2010; Sharma et al., 2010). Since the main constituent of ash content is silica, the ion- exchange reaction on the silica surface is accomplished through the substitution of protons of the surface silanol groups by the metal ions from solution as (Masoud et al., 2012)

$\mathrm{M}^{+\mathrm{n}}+\mathrm{x}(=\mathrm{SiOH})_{\mathrm{x}}^{(\mathrm{n}-\mathrm{x})}+\mathrm{xH}^{+}$

$\mathrm{Mn}^{+}=$metal ion with $\mathrm{n}^{+}$charge.
$\mathrm{SiOH}=$ group Silanol on the $\mathrm{SiO}_{2}$ surface.

$\mathrm{xH}^{+}=$number of protons released

\section{Used in ceramic industries}

RHA used in ceramic glazes (Bondioli et al., 2010). It is also used to synthesis of $(\mathrm{Pr}, \mathrm{Zr}) \mathrm{SiO}_{4}$ ceramic pigment, cordierite ceramics, $\mathrm{Si}_{2} \mathrm{~N}_{2} \mathrm{O}, \mathrm{Si}_{3} \mathrm{~N}_{4}$ and $\mathrm{SiC}$, mullite $\left(3 \mathrm{Al}_{2} \mathrm{O}_{3} \cdot 2 \mathrm{SiO}_{2}\right), \quad \mathrm{SiO}_{2}$ porous ceramic materials (Padhi and Patnaik, 1995; Bondioli et al., 2007; Chen et al., 2014; Serra et al., 2015)

\section{For synthesis of silica nano particles}

RHA is efficiently and effectively used in synthesis of silica nanoparticles in ecofriendly way (Thuadaij and Nuntiya, 2008; Premaratne et al., 2013; Sankar et al., 2016).

It is also reported $\mathrm{SiO}_{2}$ and $\mathrm{SiC}$ nanowires, and $\mathrm{SiO}_{2} / \mathrm{CaCO}_{3}$ nanocomposite prepared from RHA (Pukird et al., 2009; Morsy et al., 2014). Nanosilica is synthesised from sodium silicate solution using precipitation method. The reaction is as follows:

$\mathrm{SiO}_{2 \text { (Ash) }}+2 \mathrm{NaOH}_{\text {(Caustic soda) } \rightarrow} \mathrm{Na}_{2} \mathrm{SiO}_{3 \text { (Sodium }}$ silicate) $+\mathrm{H}_{2} \mathrm{O}$ (Water)

The silica particles were generated from the solution by adding sulfuric acid as catalyst of silica from sodium silicate by the following reaction (Rafiee et al., 2012).

$\mathrm{Na}_{2} \mathrm{SiO}_{3}+\mathrm{H}_{2} \mathrm{SO}_{4} \rightarrow \mathrm{SiO}_{2}+\mathrm{Na}_{2} \mathrm{SO}_{4}+\mathrm{H}_{2} \mathrm{O}$.

Silica nanoparticles (SNPs) are frequently used nano materials in a variety of technological applications such as industrial manufacturing, packaging, composite and ceramics materials, drug delivery, adsorption, bio sensing and catalytic applications (Ghorbani et al., 2015). 


\section{Other uses}

RHA is effectively used as pigment extender in emulsion paints (Igwebike-Ossi and Dilim, 2014; Ossi and Dilim, 2015). RHA as siliceous materials used as sorbents for the flue gas desulfurization process in small-scale industrial boilers, also it has been subsequently tested for marine diesel spill clean-up (Dahlan et al., 2006; Bazargan et al., 2014). It is used as oil absorbent for absorption of vacuum pump oil also for purifying biodiesel from waste frying oil (Tatum and Winter, 1997; Chou et al., 2001; Manique et al., 2012). A novel application of RHA is for the pre concentration of gold (Nakbanpote et al., 2000; Nakbanpote et al., 2002). Silica extracted from RHA used as corrosion inhibitor for carbon steel (Awizar et $a l ., 2013)$. RHA has been used as a support for $\mathrm{Ni}$ catalyst for various organic reactions (Chang et al., 1998). In developing countries, also it is used to reduce fatty acids from frying oils (Chou et al., 2007). Production of sodium silicate films (Kalapathy et al., 2000).

Systematic application of RH and RHA in direct manufacturing and synthesizing new materials could solve the problems of disposal and decrease the cost of waste treatments. More silica content in $\mathrm{RH}$ as compare other agriculture waste materials is an important potential for directly and indirectly application in different manner, which makes it good market valuable product. Effective application of $\mathrm{RH}$ such as fuel/electricity generation, bio ethanol production could transfer agriculture by product to valuable energy source for industrial sector. RHA also plays important role in various industrial applications such as processing of ceramic, cement, refractory industry. Biosynthesis of silica nanoparticles and its application in different field makes it valuable raw material. Application of RH might help in increasing farm economy and rural development.
Systematic approach of this material can give new birth to a new domestic and industrial sectors of Rice husk and Rice Husk Ash in India.

\section{References}

Abbas, A., and Ansumali, S. 2010. Global potential of rice husk as a renewable feedstock for ethanol biofuel production. Bio Energy Research. 3(4): 328-334.

Acharya, H. N., S. K. Dutta and Banerjee, H. D. 1980. Production of magnesium silicide and silane from rice husk ash. Solar Energy Materials. 3(3): 441-443.

Adam, F., S. Balakrishnan and Wong, P. 2006. Rice husk ash silica as a support material for ruthenium based heterogeneous catalyst. Journal of Physical Science. 17(2): 1-13.

Adebayo, R. A., and Ibikunle, O. 2014. Potentials of rice husk ash, cowdung ash and powdered clay as grain protectants against Callosobruchus maculatus (F) and Sitophilus zeamais (Mots). Applied Tropical Agriculture. 19(1): 48-53

Aderolu, A. Z., E. A. Iyayi and Onilude, A. A. 2007. Changes in nutritional value of rice husk during Trichoderma viride degradation. Bulgarian Journal of Agricultural Science. 13(5): 583-589

Aderolu, A. Z., E. A. Iyay, A. A. Onilude and Eniola I. 2004. Biodegraded rice husks in laying bird's diet: 1. Performance and egg quality parameters. Livestock Research for Rural Development 16 (1):1-5

Alvarez, J. G., Lopez, M. Amutio, J. Bilbao and Olazar M. 2015. Physical activation of rice husk pyrolysis char for the production of high surface area activated carbons. Industrial and Engineering Chemistry Research. 54(1): 7241-7250

Ammara, S., A. Fakhra and Amber A. 2014. Processing of rice and wheat husk for the potential utilization of the material for pottery products. International Research Journal of Environment Sciences. 3(1): 7-14

Arayapranee, W., N. Na-Ranong, L. Garry, and Rempel. 2005. Application of rice husk ash as fillers in the natural rubber industry. Journal of Applied Polymer Science 98(1): 34-41. 
Attharangsan, S., H. Ismail, M. Abu Bakar, J. Ismail. 2012. Carbon black (CB)/rice husk powder (RHP) hybrid filler-filled natural rubber composites: effect of $\mathrm{cb} / \mathrm{rhp}$ ratio on property of the composites. Polymer-Plastics Technology and Engineering. 51(7):655-662.

Awizar, D. A., N. K. Othman, A. Jalar, A. K. Daud, I. A. Rahman and Al-hardan, N. H. 2013. Nanosilicate extraction from rice husk ash as green corrosion inhibitor. International Journal of Electrochemical Science. 8(2): $1759-1769$.

Badar, R., and Qureshi, S. A. 2014. Composted rice husk improves the growth and biochemical parameters of sunflower plants. Journal of Botany. 2014:1-6.

Bazargan, A., J. Tan, C. W. Hui and Mckay, G. 2014. Utilization of rice husks for the production of oil sorbent materials. Cellulose. 21(3): 1679-1688

Bhagavanulu D. V. S., 2008. Effect of different ashes on the properties of turbid water. International Research Journal of Engineering and Technology. 2(1): 327

Bining, A. S., and Jenkins, B. M.1992. Thermo chemical reaction kinetics for rice straw from an approximate integral technique. American Society of Agricultural Engineers. Meeting (USA). No. 92-6001/92-6040

Bondioli, F., L. Barbieri, A. M. Ferrari and Manfredini, T. 2010. Characterization of rice husk ash and its recycling as quartz substitute for the production of ceramic glazes. Journal of the American Ceramic Society. 93(1): 121-126

Bose, S. H., and Banerjee, A. H. 1993. Electrocal, thermal, thermoelectric and related properties of magnesium silicide semiconductor prepared from rice husk. Journal of Material Science. 28(20): 5461-5468.

Chandrasekhar, S., K. G. Satyanarayana, P. N. Pramada, P. Raghavan and Gupta, T. N. 2003. Processing, properties and applications of reactive silica from rice husk-an overview. Journal of Materials Science. 38(15):31593168 .

Chandrasekhar, S., P. N. Pramada and Praveen, L. 2005. Effect of organic acid treatment on the properties of rice husk silica. Journal of Materials Science. 40(24): 6535-6544.

Chang, F. W., T. J. Hsiao and Shih, J. D. 1998. Hydrogenation of $\mathrm{CO}_{2}$ over a rice husk ash supported nickel catalyst prepared by deposition precipitation. Industrial and Engineering Chemistry Research. 37(10): 3838-3845.

Choi, N. W., I. Mori and Ohama Y. 2006. Development of rice husk-plastics composites for building materials. Waste Management. 26(2): 189-194.

Chou, K. S., Tsai, J. C and Lo C. T. 2001. The adsorption of Congo red and vacuum pump oil by rice hull ash. Bioresource Technology. 78(2):217-219.

Chuah, T. G., A. Jumasiah, I. Azni, S. Katayon and Thomas, C. S. Y. 2005. Rice husk as a potentially low-cost biosorbent for heavy metal and dye removal: an overview. Desalination. 175(3): 305-316

Cisse, I. K., and Laquerbe, M. 2000. Mechanical characterisation of filler sandcretes with RHA additions: study applied to senegal. Cement and Concrete Research. 30(1): 13-8.

Conradt, R., Pimkhaokham, P. and Leela-Adisorn, U. 1992. Nanostructured silica from rice husk. Journal of Non-Crystalline Solids. 145: 75-79

Coutinho, J. S., 2002. The combined benefits of CPF and RHA in improving the durability of concrete structures. Cement and Concrete Composites. 25(1): 51-59.

Dahlan, I., K. T. Lee, A. H. Kamaruddin and Mohamed, A. R. 2006. Key factor in rice husk ash/cao sorbent for high flue gas desulfurization activity. Environmental Science and Technology. 40(19):6032-6037.

Daifullah, A. A. M., B. S. Girgis and Gad H. M. H. 2003. Utilization of agro-residues (rice husk) in small waste water treatment plans. Materials Letters. 57(11):1723-1731

Daifullah, A. A. M., N. S. Awwad and El-Reefy S. A. 2004. Purification of wet phosphoric acid from ferric ions using modified rice husk. Chemical Engineering and Processing: Process Intensification. 43(2): 193-201

Das, G. P., and Rahman, M. M. 1997. Effect of some inert materials and insecticides against the potato tuber moth, Phthorimaea operculella in storage. International Journal of Pest Management. 43(3):247-248.

Della, V. P., I. Kuhn and Hotza, D. 2002. Rice husk ash as an alternate source for active silica production. Materials Letters. 57(4): 818821.

Dongmin, A., Y. Guo, Y. Zhu and Wang, Z. A. 2010. Green route to preparation of silica 
powders with rice husk ash and waste gas. Chemical Engineering Journal. 162(2): 509514.

Ebaid, R. A., A. A. El-Hessiwy and El-Dalil, M. 2005. Preliminary study on utilization of rice husk in rice cultivation. Egypt. Journal of Agricultural Research. 3: 369 376.

Ebaid, R. A., and El-Refaee I. S. 2007. Utilization of rice husk as an organic fertilizer to improve productivity and water use efficiency in rice fields. African Crop Science Conference Proceedings. 81: 923-1928.

El-Refaee, I. S., R. A. Ebaid and El-Rewiny, I. M. 2006. Performance of rice (Oryza sativa L.) plant under different water regimes and methods of planting. Alexandria Journal of Agricultural Research. 51(2): 47-55.

El-Weheishy, M. M., and Abd El-Hafez. A.G. 1997. Response of flooded rice to water deficit. Journal of Agricultural Research Tanta University 23: 273-288.

Fadaei, V., and Salehifar, M. 2012. Rice husk as a source of dietary fiber. Annals of Biological Research. 3:1437-1442.

Farooquea, K. N. M., Zamana, M. Halimb, S. Islama, M. Hossaina, Y. A. Mollahb and Mahmood, A. J. 2009. Characterization and utilization of rice husk ash (RHA) from rice mill of Bangladesh. Bangladesh Journal of Scientific and Industrial Research. 44(2):157162.

Ganesan, K., K. Rajagopal and Thangavel, K. 2008. Rice husk ash blended cement: assessment of optimal level of replacement for strength and permeability properties of concrete. Construction and Building Materials. 22(8):1675-1683

Ghorbani, F., Sanati, A. M. and Maleki, M. 2015. Production of silica nanoparticles from rice husk as agricultural waste by environmental friendly technique. Environmental Studies of Persian Gulf. 2:56-65

Giddel, M. R., and Jivan, A. P. 2007. Waste to wealth, potential of rice husk in India a literature review. International Conference on Cleaner Technologies and Environmental Management PEC pp 586-590

Govindarao, V. M., 1980. Utilization of rice husk. a preliminary analysis. Journal of Scientific and Industrial Research. 39(9): 495-515

Gupta, V. K., Mittal, A. Jain, R. M. Mathur and Sikarwar, S. 2006. Adsorption of Safranin-T from wastewater using waste materials activated carbon and activated rice husks. Journal of Colloid and Interface Science. 303: 80-86.

Imyim, A., and Prapalimrungsi, E. 2010. Humic acids removal from water by aminopropyl functionalized rice husk ash. Journal of Hazardous Materials. 184(1): 775-781.

Ishak, Z. A. M., and Bakar, A. A. 1995. An investigation on the potential of rice husk ash as fillers for epoxidized natural rubber (ENR). European Polymer Journal. 31(3): 256-269.

Ismail, H., H. B. Hong, C. Y. Ping and Khalil, H. P. S. 2003. Polypropylene/silica/rice husk ash hybrid composites: a study on the mechanical, water adsorption and morphological properties. Journal of Thermoplastic Composite Materials. 16(2): 121-137.

Ismail, H., L. Mega and Abdul Khalil, H. P. S. 2001. Effect of a silane coupling agent on the properties of white rice husk ashpolypropylene/natural rubber. Polymer composites. 50(5): 606-611.

Ismail, H., U. S. Ishiaku, A. R. Arinab and I. Z. A. 1997. The effect of rice husk ash as a filler for epoxidized natural rubber compounds. International Journal of Polymeric Materials and Polymeric Biomaterials. 36(1/2): 39-51.

Joseph, K. R., Toledo, B. James, S. Thomas and Carvalho, L. H. 1999. A review on sisal fiber reinforced polymer composites. Revista Brasileira de Engenharia Agricola Ambiental. 3 (3): 367-379.

Kalapathy, U. A., A. Proctor and Shultz, J. 2000. Production and properties of flexible sodium silicate films from rice hull ash. Bioresource Technology. 72(2):9 9-106.

Karera, A., S. Nargis, S. Patel and Patel M. 1986. Silicon based materials from rice husk. Journal of Scientific and Industrial Research. 45:441-448.

Kartini, K., 2011. Rice husk ash pozzolanic material for sustainability. International Journal of Applied Science and Technology. 1(6): 169178.

Khalf, A. I., Ward, A. A. 2010. Use of rice husks as potential filler in SBR/LLDPE blends in the presence of maleic anhydride. Journal of Material Design. 31: 2414-2421.

Koteswara, R. D., and Pranav, R. T. 2011. Stabilization of expansive soil with rice husk 
ash, lime and gypsum-an experimental study. International Journal of Engineering Science and Technology. 3(11): 8076-8085.

Krishnarao, R. V., and Godkhindi M. M. 1992. Effect of $\mathrm{Si}_{3} \mathrm{~N}_{4}$ additions on the formation of $\mathrm{SiC}$ whiskers from rice husks. Ceramics International. 18(3): 185-191

Kumar, A., K. Mohant, D. Kumar and Parkash, O. 2012. Properties and industrial applications of rice husk a review. International Journal of Emerging Technology and Advanced Engineering. 10: 2250-2459.

Kumar, V. S., Sinha, M. S. Saini, B. K. Kanungo and Biswas, P. 2010. Rice husk as reinforcing filler in polypropylene composites. Reviews in Chemical Engineering. 26(1-2): 41-53.

Lata, S., and Samadder, R. 2014. Removal of heavy metals using rice husk: a review. International Journal of Environmental Research and Development. 4: 165-170

Lee, C. K., K. S. Low, S. C. Liew and Choo, C. S. 1999. Removal of arsenic (V) from aqueus solution by quaternized rice husk. Environmental Technology. 20(9): 971-978.

Lennox, R., and Mackenzie, M. 2008. Eco-road building for emerging economies: An initial scan for promising alternative technologies. pp 1-19

Lim, S. L., T. Y. Wu, E. Y. Sim, P. N. Lim and Clarke, C. 2012. Biotransformation of ricehusk into organic fertilizer through vermicomposting. Ecological Engineering. 41: 60-64

Lyenagbe, B., Ugheoke and Othman, M. 2012. A critical assessment and new research directions of rice husk silica processing methods and properties. Maejo international journal of science and technology. 6(3): 430448.

Malhotra, C., R. Patil, S. Kausley and Ahmad, D. 2013. Novel uses of rice-husk-ash (a natural silica-carbon matrix) in low-cost water purification applications. AIP Conference Proceeding

Malik, S., and Arora, B. 2015. Effect of fly ash and rice husk ash on the properties of burnt clay bricks. International Journal of Innovative Research in Computer Science and Technology.

Manique, M. C., C. S. Faccini, B. Onorevoli, E. V. Benvenutti and Caramao, E. B. 2012. Rice husk ash as an adsorbent for purifying biodiesel from waste frying oil. Fuel. 92(1):
56-61.

Mansaray, K. G., and Ghaly, A. E. 1999. Thermal degradation of rice husks in an oxygen atmosphere. Energy Sources. 21(5): 453-466.

Mehta, A., and Ugwekar, R. P. 2015. Extraction of silica and other related products from rice husk. Internationl Journal of Engineering Research and Applications. 5: 43-48

Mehta, P. K., 1977. Properties of blended cements made from rice husk ash. Journal Proceedings. 74(9): 440-442.

Mehta, P. K., and Haxo, H. E. 1975. Ground ricehull ash as filler for rubber. Rubber Chemistry and Technology. 48(2): 271-287.

Mohamed, R. M., I. A. Mkhalid and Barakat, M. A. 2015. Rice husk ash as a renewable source for the production of zeolite $\mathrm{NaY}$ and its characterization. Arabian Journal of Chemistry. 8(1): 48-53.

Monga, R. S., G. R. Kale and Guhe, S. Y. 2015. Chemical looping combustion of rice husk. International Journal of Engineering Research and Applications. 5(5):132-138.

More, A. S., A. Tarade and Anant, A. 2014. Assessment of suitability of fly ash and rice husk ash burnt clay bricks. International Journal of Scientific and Research Publications. 4(7):1-6

Morsy, F. A., S. M. El-Sheikh and Barhoum, A. 2014. Nano-silica and $\mathrm{SiO}_{2} / \mathrm{CaCO}_{3}$ nanocomposite prepared from semi-burned rice straw ash as modified papermaking fillers. Arabian Journal of Chemistry.

Munaf, E., and Zein, R. 2010. The use of rice husk for removal of toxic metals from waste water. Environmental Technology. 18(3):359-362.

Muntohar, A. S., 2002. Utilization of uncontrolled burnt rice husk ash in soil improvement. Dimensi Teknik Sipil. 4(2): 100-105.

Muthadhi, A., Anitha, R. and. Kothandaraman, S. 2007. Rice husk ash properties and its uses: a review. Journal of the Institution of Engineers. 88(5): 50-56.

Nakbanpote, W., P. Thiravetyan and Kalambaheti, C. 2000. Preconcentration of gold by rice husk ash. Mining engineering. 13(4): 391400.

Nakbanpote, W., P. Thiravetyan and Kalambaheti, C. 2002. Comparison of gold adsorption by Chlorella vulgaris, rice husk and activated carbon. Minerals Engineering. 15(7): 549552.

Naskar, M. K., and Chatterjee, M. 2004. A novel 
process for the synthesis of cordierite $\left(\mathrm{Mg}_{2} \mathrm{Al}_{4} \mathrm{Si}_{5} \mathrm{O}_{18}\right)$ powders from rice husk ash and other sources of silica and their comparative study. Journal of the European Ceramic Society. 24(13): 3499-3508.

Nassar, M. A., 2007. Composites from sawdust-rice husk fibers. Polymer-Plastics Technology and Engineering. 45(5):441-446.

Niyomwas, S., 2009. Synthesis and characterization of silicon-silicon carbide composites from rice husk ash via self-propagating high temperature synthesis, Journal Metals Material and Minerals. 19(2): 21-25.

Nyachaka, C. J., D. S. Yawas and Pam, G. Y. 2013. Bio-ethanol production from rice husk and performance test of petrol and bioethanol blends in a spark ignition engine. International Journal of Engineering Research and Technology. 2:1-6

Ossi, I., and Dilim, C. 2015. Pigment extender properties of rice husk ash in emulsion paint. International Journal of Innovative Research in Science, Engineering and Technology 4: 6821-6829.

Padhi, B. K., and Patnaik, C.1995. Development of $\mathrm{Si}_{2} \mathrm{~N}_{2} \mathrm{O}, \mathrm{Si}_{3} \mathrm{~N}_{4}$ and $\mathrm{SiC}$ ceramic materials using rice husk. Ceramics International. 21(3): 213-220

Paneru, R. B., and Shivakoti, G. P. 2000/2001. Use of botanicals for the management of pulse beetle (Callosobruchus maculatus F.) in lentil. Nepal Agriculture Research. 4\&5: 2730.

Panthapulakkal, S., S. Law and Sain, M. 2005. Enhancement of process ability of rice husk filled high-density polyethylene composite profiles. Journal of Thermoplastic Composite Materials. 18(5): 445-458.

Patel, M., A. Karera and P. Prasanna 1987. Effect of thermal and chemical treatment on carbon and silica contents in rice husk. Journal of Material Science. 22(7): 2457-2464

Patil, R., R. Dongre and Meshram, J. 2014. Preparation of silica powder from rice husk. Journal of Applied Chemistry. 27: 26-29.

Pode, R., 2016. Potential applications of rice husk ash waste from rice husk biomass power plant. Renewable and Sustainable Energy Reviews. 53: 1468-1485

Prasara, A.J., and Grant, T. 2011. Comparative life cycle assessment of uses of rice husk for energy purposes. International Journal of Life Cycle Assessment 16(6): 493-502
Premalal, H. G. B., Ismail, H. and Baharin, A. 2003. Effect of processing time on the tensile, morphological and thermal properties of rice husk powder-filled polypropylene composites. Polymer-Plastics Technology Engineering. 42(5): 827-851.

Premalal, H. G., H. Ismail and Baharin, A. 2002. Comparison of the mechanical properties of rice husk powder filled polypropylene composites with talc filled polypropylene composites. Polymer Testing. 21(7): 833839.

Priyadharshini, J., and Seran, T., 2010. Paddy husk ash as a source of potassium for growth and yield of cowpea (Vigna unguiculata L.) Journal of Agricultural Sciences. 4(2): 67-76.

Pukird, S., P. Chamninok, S. Samran, P. Kasia, K. Noipa and Chow, L. 2009. Synthesisand characterization of $\mathrm{SiO}_{2}$ nanowires prepared from rice husk ash. Journal of metals, materials and minerals. 19(2): 33-37.

Rafiee, E., S. Shahebrahimi, M. Feyzi, and Shaterzadeh, M. 2012. Optimization of synthesis and characterization of nanosilica produced from rice husk (a common waste material). International Nano Letters. 2(1): 29-37.

Rahman, I. A., B. Saad, S. Shaidan and Sya Rizal, E. S. 2005. Adsorption characteristics of malachite green on activated carbon derived from rice husks produced by chemical thermal process. Bioresource Technology. 96(14): 1578-1583.

Rahman, M.A., 1988. Effect of rice husk ash on the properties of bricks made from fired lateritic soil-clay mix. Materials and Structures. 21(3): 222-227.

Rama- Rao, G., A. R. K. Sastry and Rohatgi, P. K. 1989. Nature and reactivity of silica available in rice husk and its ashes. Journal of Materials Science. 12(5): 469-479.

Real, C. M., Alcala and J. M. Criado 1996. Preparation of silica from rice husks. Journal of the American Ceramic Society. 79(8): 2012-2016.

Rozainee, M., S. P. Ngo, A. A. Salema, K. G. Tan, M. Ariffin and Zainura, Z. N. 2008. Effect of fluidising velocity on the combustion of rice husk in a bench-scale fluidised bed combustor for the production of amorphous rice husk ash. Bioresource Technology. 99(4): 703-713.

Saha, B. C., and Cotta, M. A. 2007. Enzymatic 
saccharification and fermentation of alkaline peroxide pretreated rice hulls to ethanol. Enzyme and Microbial Technology. 41(4): 528-532

Sarang, M., S. Bhattacharyya and Behera, R. C. 2009. Rice effect of temperature on morphology and phase transformations of nanocrystalline silica obtained from rice husk. Phase transitions: a multinational journal. 82(5): $377-386$.

Serra, M. F., M. S. Conconi, M. R. Gauna, G. Suarez, E. F. Aglietti and Rendtorff, N. M. 2016. Mullite $\left(3 \mathrm{Al}_{2} \mathrm{O}_{3} \cdot 2 \mathrm{SiO}_{2}\right)$ ceramics obtained by reaction sintering of rice husk ash and alumina, phase evolution, sintering and microstructure. Journal of Asian Ceramic Societies. 4(1): 61-6

Sevdalina, T., G. Svetlana, and Lyubomir. 2012. Obtaining some polymer composites filled with rice husks ash-a review. International Journal of Chemistry. 4(4): 62-89.

Shak, K. P. Y, T. Y., Wu, S. L. Lim and Lee, A. C. 2014. Sustainable reuse of rice residues as feedstocks in vermicomposting for organic fertilizer production. Environmental Science and Pollution Research. 21(2): 1349-1359.

Sharma, P., Kaur, R., Chinnappan, B. and Chung, W. J. 2010. Removal of methylene blue from aqueous waste using rice husk and rice husk ash. Desalination 259(1):249-257

Shazia, O. W. M. R., M. Masunga, R. Makundi, R. N. Misangu, B. Kilonzo, M. Mwatawala, $\mathrm{H}$. F. Lyimo, C. G. Ishengoma, D. G. Msuya and Mulungu, L. S. 2006. Control of cowpea weevil (Callosobruchus maculates L.) in Stored Cowpea (Vigna unguiculatus L.) grains using botanicals. Asian Journal of Plant Sciences. 5: 91-97

Shelke, V. R., S. S. Bhagade and Mandavgane, S. A. 2010.Mesoporous silica from rice husk ash. Bulletin of Chemical Reaction Engineering and Catalysis 5(2): 63-67.

Shqueir, A. A., Brown, D. L. and Klasing, K. C., 1989. Canavanine content and toxicity of Sesbania leaf meal for growing chicks. Animal Feed Science Technology. 25(1-2): 137.

Shwetha, M. K., H. M. Geethanjali and Chowdary K. 2014. A great opportunity in prospective management of rice husk. International Journal of Commerce and Business Management. 7(1): 176-180.

Singh, D., R. Kumar, A. Kumar and Rai, K. N.
2008. Synthesis and characterization of rice husk silica, silicacarbon composite and $\mathrm{H}_{3} \mathrm{PO}_{4}$ activated silica. Ceramica. 54(330): 203-212.

Singh, T., 2000. The tribune, online edition. Chandigarh, India.

Soltan, N., A. Bahrami, M. I. Pech-Canul and Gonzalez, L. A. 2015. Review on the physicochemical treatments of rice husk for production of advanced materials. Chemical Engineering Journal. 264: 899-935

Soltani, N., Bahrami A, Pech-Canul M I and Gonzalez L A.2015. Review on the physicochemical treatments of rice husk for production of advanced materials. Chemical Engineering Journal. 264: 899-935.

Srivastava, A. K., P. Agrawa and Rahiman, A. 2014. Delignification of rice husk and production of bioethanol. International Journal of Innovative Research in Science, Engineering and Technology. 3(3): 10187-10194.

Sun, L., and Gong, K. 2001. Silicon-based materials from rice husks and their applications. Industrial \& Engineering Chemistry Research. 40(25): 5861-5877.

Supakorn, P., C. Pattanasuk S. Supon, K. Pristanuch, N. Kiattisak and Lee, C. 2009. Synthesis and characterization of $\mathrm{SiO}_{2}$ nanowires prepared from rice husk ash. Journal of Metals, Materials and Minerals. 19(2): 33-37.

Supitcha, R., Wachira, P. and Natthapong, S. 2009. Preparation of silica gel from rice husk ash using microwave heating. Journal of Metals, Materials and Minerals. 19(2): 45-50.

Sutas, J., A. Mana and L. Pitak 2012. Effect of rice husk and rice husk ash to properties of bricks. Procedia Engineering 32: 1061-1067.

Tatum, N., and Winter, N. 1997. Rice hull ash as a potting substrate for bedding plants. Southern Nursery Association conference pp 121-122.

Tongpoothorn, W., M. Sriuttha, P. Homchan, S. Chanthai and Ruangviriyachai, C. 2011. Preparation of activated carbon derived from Jatropha curcas fruit shell by simple thermochemical activation and characterization of their physico-chemical properties. Chemical Engineering Research and Design 89(3): 335340.

Tzong-Horng, L., 2004. Evolution of chemistry and morphology during the carbonization and combustion of rice husk. Carbon 42(4): 785794.

Ugheoke, B. M., E. O. Onche, O. N. Namessan and 
Asikpo, G. A. 2006. Property optimization of Kaolin - rice husk insulating fire bricks. Journal of Practices and Technologies. 9: 167-178

Van, K. L. and Thi, T. T. L. 2014. Activated carbon derived from rice husk by $\mathrm{NaOH}$ activation and its application in super capacitor. Material International 24(3): 191-198

Velupillai, L., D. B. Mahin, J. W. Warshaw and Wailes, E. J. 1997. A study of the market for rice husk-to-energy systems and equipment, Louisiana State University, Baton Rouge, Louisiana, USA.

Wahab, O. A., A. E. Nemr, A. E. Sikaily and Khaled, A. 2005. Use of rice husk for adsorption of direct dyes from aqueous solution: a case study of direct F. Scarlet. Egyptian Journal of Aquatic Research 31(1): 1110-0354.

Wang, H. P., K. S. Lin, Y. J. Huang, M. C. Li, and Tsaur, L. K.1998. Synthesis of zeolite ZSM48 from rice husk ash. Journal of Hazardous Materials 58(1): 147-152.

Watari, T., A. Nakata, Y. Kiba, T. Torikai and Yada, M. 2006. Fabrication of porous $\mathrm{SiO}_{2} / \mathrm{C}$ composite from rice husks. European Ceramic Society. 26(4): 797-801.

Watile, R. K., S. K. Deshmukh, P. V. Durge and Yawale, A. D. 2015. Utilization of rice husk for production of clay brick. International Journal of Research in Advent Technology. $1^{\text {st }}$ International Conference on Advent Trends in Engineering, Science and Technology "ICATEST 2015" pp 199-203

Wu, M., Q. Zha, J. Qiu, Y. Guo and Shang, H. 2004. Preparation and characterization of porous carbons from PAN-based preoxidized cloth by $\mathrm{KOH}$ activation. Carbon 42(1): 205-210.

Xu, H., B. Gao, H. Cao, X. Chen, L. Yu, K. Wu, L. Sun, X. Peng and Fu, J. 2014. Nanoporous activated carbon derived from rice husk for high performance super capacitor. Journal of Nanomaterials 2014: 1-7

Yadav, J. P., and Singh, B. R. 2011. Study on comparison of boiler efficiency using husk and coal as fuel in rice mill. SAMRIDDHI-A Journal of Physical Sciences, Engineering and Technology. 2: 2229-7111

Yalcin, N., and Sevinc, V. 2000. Studies of the surface area and porosity of activated carbons prepared from rice husks. Carbon 38(14):1943-1945.

Zhang, M. H., R. Lastra and Malhotra, V. M. 1996. Rice-husk ash paste and concrete: Some aspects of hydration and the microstructure of the interfacial zone between the aggregate and paste. Cement and Concrete Research. 26(6): 963-977.

Zurina, M., H. Ismail, A. A. Bakar 2004. Partial replacement of silica by rice husk powder in polystyrene-styrene butadiene rubber blends. Journal of Reinforced Plastics and Composites. 23(13): 1397-1408.

\section{How to cite this article:}

Patil Nita Babaso and Sharanagouda, H. 2017. Rice Husk and Its Applications: Review. Int.J.Curr.Microbiol.App.Sci. 6(10): 1144-1156. doi: https://doi.org/10.20546/ijcmas.2017.610.138 